\title{
O MOTIM, DE MiGUEL FRANCO, UM CICLO SAGRADO DE RENOVAÇÃO
} Flavio Felico Botton*

Resumo: Este artigo tem por objetivo analisar os elementos cronotópicos da peça de Miguel Franco, O Motim (1963), procurando compreender o sentido que eles conferem à peça. O que este artigo pretende é analisar a peça de Miguel Franco, limitando essa empresa aos seus elementos cronotópicos, procurando compreender os sentidos que são alcançados por meio dos dados de tempo e espaço.

Palavras-chave: Teatro (literatura) (História e Crítica) - Portugal. Teatro histórico. Miguel Franco. O Motim.

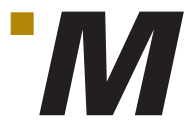

iguel Franco nasceu em Leiria, em 1918, e atuou no teatro amador de sua cidade, sendo várias vezes premiado como encenador e como ator. Na década de 1960, durante a ditadura salazarista, Franco leva ao Teatro Avenida de Lisboa, por meio da consagrada Companhia Rey Colaço - Robles Monteiro, sua mais importante peça de teatro histórico, O motim (1963), que retoma os eventos históricos ocorridos após o levante do povo da cidade do Porto contra a criação da Companhia dos Vinhos do Alto Douro, criada pelo ministro de D. José, o Marques de Pombal.

Faz-se a noite de abertura em um sábado, 6 de fevereiro de 1965. Para a estreia da temporada, estavam presentes importantes homens do governo português, posto que fora esse um dos grandes responsáveis pelo financiamento da reforma do Teatro Avenida. Via-se na plateia, além do presidente Américo Tomás e sua esposa, os ministros da Educação Nacional e das Corporações e também aquele que seria, futuramente, o sucessor político de Oliveira Salazar, o professor Marcelo Caetano. 
No dia posterior à estreia, os jornais fizeram extensa louvação às performances dos atores, do encenador e ao texto de Miguel Franco, que foi chamado ao palco e recebeu os aplausos com a direção da companhia, na pessoa de Amélia Rey Colaço. Tempos depois, um bilheteiro do Teatro Avenida contaria a Miguel Franco que, ao fim daquela primeira encenação, o Presidente Tomás e os ministros de Estado desciam a estreita escadaria que vinha dos camarotes quando Marcelo Caetano disparou: "Então agora o governo subsidia motins?!" (apud BOTTON, 2015).

Às 14 horas do que seria o quinto dia de apresentações, sob o testemunho de atores que chegavam ao trabalho e de espectadores que aguardavam a abertura das bilheterias, a Polícia Internacional e de Defesa do Estado (PIDE) invadiu a casa de espetáculos, intimou os bilheteiros a suspenderem a abertura dos guichês, rasgou e confiscou os cartazes da peça. As apresentações foram brutalmente suspensas e a peça foi retirada de cena pelo aparelho de repressão do regime salazarista. Tornava-se claro que o conflito do tempo histórico da peça acabava por desvelar outros conflitos que, mesmo estando parcialmente sufocados, fremiam por vir à superfície.

Forçoso dizer que os interrogatórios conduzidos pelo desumano escrivão da alçada, personagem da peça de Franco, assemelhavam-se por demasia aos atrozes inquéritos da PIDE, assim como a situação da população portuense do século XVIII, calada pelos emissários de Sebastião José de Carvalho, aproximava-se muito da situação vivida pela plateia portuguesa na segunda metade do século XX. A confirmar essa possibilidade está o fato de que, em alguns momentos das inquirições do escrivão da alçada, pessoas da plateia se viravam para observar se havia expressão de mal-estar por parte dos convidados do camarote do presidente.

\section{O ENTREChO}

A peça baseia-se nos eventos históricos do motim do Porto e dispõe-se, em seu primeiro ato, a apresentar as principais personagens e sua descrição do que teria sido o movimento popular que acabara de ocorrer, sempre pelo ponto de vista das personagens das classes mais baixas e dos comerciantes do Porto. Estão todos reunidos na taberna de Tomás Pinto e o clima é de festa, pois até o momento o povo parece ter conseguido o que queria: o fim do monopólio da Companhia sobre a venda dos vinhos produzidos pelos vinicultores da região.

Em folguedo carnavalesco, após terem as suas pretensões atendidas, as saudações dos frequentadores da taberna associam o poder do rei com o povo, opondo-se às fraudes da Companhia. Assim, a principio, o poder popular estaria legitimamente associado ao poder real. O povo feliz, festejando e tomando seu destino nas próprias mãos aparece em mais de uma oportunidade neste primeiro ato. Além da alegria e da vida em sua plenitude, mais um elemento é marca do primeiro ato. Podemos, em várias ocasiões, notar a presença das discussões que transcorrem livremente entre os frequentadores da taberna. Fala-se sobre o trabalho, sobre as leis e sobre o vinho.

Destarte, no espaço popular da taberna, todas as conversas são permitidas. Vemos desde as opiniões mais simples e aparentemente descompromissadas, como as do Profeta, um "bêbado filósofo" e vaticinador, feitas em tom de embriaguez ou de poesia, até as discussões do taberneiro Tomás Pinto com o Juiz do Povo ou com o advogado Nicolau Araújo. 
Ainda nesse momento de congraçamento e liberdade, o vinho aparece como símbolo da vida, que, segundo o Profeta, dá asas ao homem, igualando-o aos pássaros. Sendo assim, quem controla o vinho controla a vida do Porto ou, nas palavras do Juiz do Povo, ele é a "grande vida do Porto" (FRANCO, 1963, p. 34).

No segundo ato, começam as consequências do levante. Por ordem de Sebastião José de Carvalho, está instalada uma alçada ${ }^{1}$ no Porto para interrogatório e julgamento dos amotinados. Há uma grande centralização do poder nas mãos do cruel escrivão José Mascarenhas, filho do presidente do tribunal, João Pacheco Pereira Vasconcelos. Alguns acusados são interrogados de forma violenta e outros são torturados. O andamento do ato se faz quase que inteiramente no ritmo dos interrogatórios brutalmente conduzidos por José de Mascarenhas. São chamados o Negres, o Caetano, o advogado Nicolau da Costa Araújo, Páscoa e Tomás Pinto, dono da taberna em que todos se reuniam e um dos líderes do levante.

Os temas relevantes nesse ato são muitos, mas limitamo-nos a mencionar a questão da legitimidade do poder, como é feita, por exemplo, no discurso de abertura dos trabalhos por Mascarenhas e na cena em que reaparece o Juiz do Povo, subjugado pelo escrivão da alçada, que veremos a seguir.

Ao fim do ato, um grande golpe se desenha nas atitudes e palavras de Mascarenhas, com sua ferocidade usual. O juiz do povo ${ }^{2}$, representante do interesse popular nas questões, tem o seu poder legítimo usurpado e sua pessoa aviltada pelo escrivão. Chegando próximo à janela, perto de onde se encontra o povo reunido, o escrivão clama:

José de Mascarenhas: Povo do Porto! Eis o teu juiz! (E num largo gesto, arranca-lhe da cabeça a cabeleira e ergue-a no ar, e depois bate-lhe com ela na cara, de um lado e de outro, e a seguir muitas vezes, freneticamente. Lisboa está todo metido para dentro de si. Ouvem-se vozes no povo longe. Então José de Mascarenhas, enchendo o peito, cospe-lhe fortemente na face). (FRANCO, 1963, p. 116).

Vê-se assim que, não apenas no aspecto simbólico, mas também em seus aspectos legais, a atuação de Mascarenhas configura um golpe contra a autoridade da cidade, cujo poder é exercido em nome da representação popular.

No terceiro e último ato, o mais breve de todos, os condenados aguardam a execução, e o clima, lúgubre e funesto, em nada mais lembra os festivos homens do primeiro ato. São feitas referências a um "mundo ao contrário" e ao homem como "coisa com razão", assim como ao destino dos que não se sujeitam ao poder totalitário. No entanto, o que sobra desses acontecimentos não é a estupefação por ver sacrificado sem misericórdia todo o povo da cidade (na pessoa, em especial, do Juiz do Povo). Aquilo que poderia gerar imobilidade suscita, por outro lado, a resistência. Esse é o tema mais relevante do terceiro ato.

\footnotetext{
Alçada (Ant.): tribunal coletivo e ambulante que, visitando os povos, lhes administrava justiça.

Desde o reinado de D. João I (1385-1433), "o Juiz do povo levava à presença do rei as petições do povo, perfilhadas pela casa dos vinte e quatro; podia falar com o monarca nas audiências do sábado, quando também eram recebidos os ministros e os fidalgos; conservava - se junto do soberano nas reuniões de cortes e por ocasião dos juramentos dos princípios". MATOSO apud OLIVEIRA, Aline Cristina da Silva. Homens de ofício: práticas políticas durante o reinado de d. João I de Portugal (1385-1433).
} 
A resistência aparece na fala do Profeta, que compara os homens que resistem aos vaga-lumes ("luzicú”):

Profeta: [...] aquela luzinha nunca se apaga, nunca... nem mesmo depois de mortos...; os garotos esbagaçam-nos, esbagaçam-nos..., mas aquela luz fica sempre, derretida a luzir nas mãos... E quando morre um "luzicú", a gente vê mesmo que morreu um "luzicú”... que morreu alguma coisa... que morreu a modos que alguém..!. (FRANCO, 1963, p. 123).

A luz, iluminação simbólica do saber e da razão, vem do homem que resiste, e ela sobrevive após a sua morte. A personificação dos heróis que resistem aparece na própria ambiguidade do pronome "nos", que pode se referir aos vaga-lumes "esbagaçados" pelos garotos, mas, por outro lado, também se refere à primeira pessoa do plural na fala do Profeta, como se os violentados fossemos "nós", não mais pelos meninos, mas pelos usurpadores do poder, que, se o fossem legitimamente, deveriam representar a todos.

A contundente resistência de Tomás Pinto chega ao seu auge na última cena, em que o taberneiro, em fúria, "morde selvaticamente o pescoço de Mascarenhas [...] que está brutalmente ensanguentado" (FRANCO, 1963, p. 134). Nesse momento, fecha-se a metáfora do vinho como a vida e o sangue a circular nas veias da cidade do Porto. Se a vida lhe foi tomada, é preciso resgatá-la, nem que seja à força.

\section{Cronotopo: ESPAÇO E TEMPO - UM CICLO SAGRADO DE RENOVAÇÃo}

O conceito bakhtiniano de cronotopo ${ }^{3}$ reporta-se às relações entre tempo e espaço na obra literária e pode assumir duas formas de abordagem, sintetizadas por Clark (2004). Primeiro, em seu sentido restrito, como elemento de uma narrativa que pode ser analisado. Segundo, em um caráter genérico, de estruturas que se repetem e que acabam por assumir um aspecto de elocução, como um lugar-comum, em que o apropriar-se de seus elementos faz com que o texto passe a compartilhar algumas das características do texto-fonte. Talvez os dois sentidos do termo sejam perceptiveis na peça de Miguel Franco.

Pode-se afirmar que as relações tempo e espaço, juntamente com a história do país, são elementos estruturantes do trabalho de Franco. Com isso, queremos dizer que $O$ motim só assume o seu significado integral e complexo se percebido em seus elementos cronotópicos. Em outras palavras, a taberna e o carnaval, assim como o período quaresmal e as estações do ano, em síntese, o conjunto de elementos referentes ao tempo e ao espaço, ostentam um papel fundamental na compreensão da peça. Sendo assim, vejamos em que espaço e em que tempo se desenvolve o entrecho da peça e a que outros caminhos eles nos levam.

Curiosamente, toda a ação da peça se passa no mesmo espaço: a taberna de Tomás Pinto. Mesmo após a formação da Alçada a julgar e a condenar os amotinados, a ação permanece no interior do mesmo local. Também no terceiro ato, em que os condenados aguardam a hora da execução da sua sentença, todos estão ainda

3 Optou-se por fazer uso da grafia "cronotopo", conforme tradução de Aurora Fornoni Bernardini et al., da 6a edição de BAKHTHIN, Mikhail. Questões de literatura e de estética - a teoria do romance. HUCITEC-UNESP, 2010. São Paulo: Hucitec-Unesp, 2010. 
na taberna, agora "transformada para recolher em oratório os condenados, homens e mulheres, do motim de Fevereiro de 1757" (FRANCO, 1963, p. 117).

No primeiro ato, a ação se passar em uma taberna não causa estranheza, posto que a situação trate justamente da venda monopolizada de vinho, que prejudica as tabernas e o povo. Assim, ao terem a sensação de que haviam conseguido o que queriam, todos voltam a se reunir na taberna de Tomás Pinto. Nessa ocasião, vemos uma ambientação de alegria, efusão e congraçamento. Em rubricas, temos várias confirmações dessa qualificação para o espaço, por exemplo: "Gente do povo enche a adega, muitos mascarados, maltrapilhos [...]. Garotos. Homens congestionados, enrouquecidos, rodeando chefes. Continuam os vivas" (FRANCO, 1963, p. 21).

Ainda assim, pode parecer incomum que uma alçada, um tribunal, ainda que itinerante, acabe por se instalar em local tão informal, como acontece no segundo ato. Para que seja justificado o fato de a ação continuar na mesma taberna, o presidente desembargador, João Pacheco, afirma que "É dos mais prudentes e sábios preceitos proceder a certos interrogatórios no próprio sítio da perpetração dos delitos, ou da sua maquinação, ou mesmo só de sua idealização" (FRANCO, 1963, p. 51).

Segundo João Pacheco, o ambiente em que se deu o "conluio" seria mais propício para o surgimento da verdade no momento dos interrogatórios. Porém, um pouco além dessa explicação, de certo modo, processual ou jurídica, é possivel ver que a permanência no mesmo espaço é entremeada por diversas transformações significativas que vão sendo realizadas no decorrer dos atos.

Como dito, o primeiro ato é de congraçamento, mas na abertura do segundo, a descrição diferente do espaço se faz perceber:

Ainda a mesma cena. A adega está tal e qual, só que parece ter adormecido. Tudo arrumado, encostado, sem vida. [...] Em cena, dois soldados do regimento de Infantaria do Minho. Encostadas ao balcão (este agora foi empurrado até junto das pipas), as suas armas; em cima, os seus barretes. (FRANCO, 1963, p. 47).

Com essa breve exposição, já é possivel perceber o quanto a taberna está diferente. Onde havia felicidade, agora há dormência e onde antes estavam os homens a comemorar, agora se descreve a "falta de vida". A explicação dessa mudança se faz logo em seguida: a presença de um poder brutal e com legitimidade questionável (os soldados e a própria alçada) faz com que o ambiente perca as suas qualidades iniciais. Pode-se perceber inclusive a ausência de um espaço fundamental para a taberna, o "atrás do balcão", móvel cuja posição foi deslocada para abrir espaço para o tribunal. Após o breve diálogo entre os dois soldados, que só faz confirmar a falta de reconhecimento da legitimidade do poder da alçada, ouve-se "[...] barulho de armas. Abre-se a porta e entra uma força de 10 soldados de Infantaria do Porto, que abre alas para dar passagem à Alçada, magistrados e funcionários. Com ela, vêm altas patentes militares [...]" (FRANCO, 1963, p. 49).

Após esse episódio, como na composição em friso de quadros de alta solenidade, como a Coroação da Imperatriz Josefina, de Jacques Louis David, ou a Coroação de D. Pedro I, nas tintas de Jean Baptiste Debret, faz-se um verdadeiro desfile de autoridades. Após a entrada de todas as "altas patentes", a alçada toma os mochos que eram parte da mobília da taberna e neles assenta os acusados. 
Percebe-se, dessa forma, que um poder exterior invade o espaço da liberdade dos homens, o local em que, como vimos, discutia-se abertamente sobre todos os assuntos.

As mudanças, no entanto, não param por aí. Na abertura do terceiro ato:

A mesma cena de sempre. Já nada recorda a taberna. Foi transformada para recolher em oratório os condenados [...] e os frades que os estão acompanhando, ouvindo de confissão e rezando com eles. Nas mais várias posturas, deitados, espojados ou encostados às paredes, os desgraçados vivem horas de um pavor indizivel [...]. Longos gemidos cortam o negrume... Choros baixinhos, desfiados, não têm mais fim [...]. Tilinta uma campainha [...] pedindo orações para os condenados. (FRANCO, 1963, p. 118).

Como a própria rubrica esclarece, nada mais lembra a expansiva alegria do ambiente do primeiro ato. Temos agora um espaço ligado à condenação e à mor te. Padres tomam confissões e ouvem-se apenas lamentações (gritos de "pavor e histerismo", FRANCO, 1963, p. 119) o que compõe uma ambientação de extenuação e esgotamento, que nos remete à proximidade do fim.

Com essas anotações sobre o espaço e a ambientação da peça, percebe-se que a caracterização do ambiente caminha paralelamente ao desenvolvimento do entrecho, ou seja, o espaço que, no primeiro ato, pertencia a todos os homens e mulheres, um local de liberdade de expressão em que todos os assuntos eram permitidos, é brutalmente invadido. Por isso, no segundo ato, ele se transforma em um cenário sem vida, adormecido por conta da intromissão do poder repressivo. A consolidação dessa força coerciva, no terceiro ato, transforma o espaço de congraçamento em espaço de morte e lamentação.

Em paralelo, da mesma forma, correm os marcos temporais do entrecho. Ainda que respeitadas as balizas históricas, utilizando as datas registradas nos autos, a peça faz ressaltá-las em seus significados possivelmente simbólicos. O motim tem seu início em época de entrudo e, a partir daí, é simples lembrar o significado comum dessa festa popular. A princípio, festa de liberdade, de danças e de embriaguez, ligada, portanto, ao vinho. A liberdade transborda e, nas palavras do Profeta, "Hoje nem os bichos ficam nas tocas" (FRANCO, 1963, p. 17).

Ainda assim, é interessante ressaltar dois pontos. Primeiramente, o chamado reinado de Momo é um tempo de alegria por, entre outros motivos, ser permitida a "vida pelo avesso". Como resume Bakhtin, no carnaval

[...] todos os participantes são ativos, todos participam da vida carnavalesca. Não se contempla [...] vive-se uma vida carnavalesca. Esta vida é uma vida desviada da sua ordem habitual, em certo sentido, uma "vida às avessas", um "mundo invertido". As leis, proibições e restrições, que determinavam o sistema e a ordem da vida comum, isto é, extracarnavalesca [...]. (BAKHTIN, 2005, p. 122-123).

Em outras palavras, é consentida a subversão dos papéis sociais tradicionais e oficiais. Homens podem se vestir como mulheres, assim como pobres miseráveis podem ser reis. Dessa maneira se encontram os homens na taberna na abertura da peça: livres de seus papéis sociais por meio de suas máscaras ou 
com suas "caras caiadas ou enfarruscadas" (FRANCO, 1963, p. 21). No entanto, a sensação de terem conseguido subverter uma situação social adversa, acreditando estarem libertos do jugo da companhia, contribui decisivamente com esse sentimento de liberdade. Esse comportamento, porém, não poderia ficar impune, pois a festa popular, sendo o carnaval a sua mais perfeita representação, é um tempo em que o golpe e a injúria constituem "atos simbólicos dirigidos contra a autoridade suprema, contra o rei” (BAKHTIN, 1999, p. 171).

Ao fim, portanto, percebemos que o mundo que os amotinados julgavam "com razão", não é verdadeiro. O mundo ao avesso estava representado pelo entrudo, no breve momento, passageiro e ilusório, de liberdade. O mundo real é aquele em que, passado o folguedo, "ninguém se salva" (FRANCO, 1963, p. 124).

Outro ponto que traz interesse ao tempo de entrudo é que, originalmente, o seu significado é de "introito" ou "introdução" ao período quaresmal (AMORIM, 2007). Assim, podemos considerar que, após a festa do entrudo, começa um período especialmente importante na liturgia católica, ligado à preparação para a Páscoa ${ }^{4}$. Esse é um tempo de recolhimento um tempo de preparação que é feita por meio de caridade e orações, mas também por meio do jejum, da abstinência e de mortificações. Como é possivel perceber, há também uma relação importante com o entrecho da peça, pois, após o primeiro ato, os protagonistas do motim são presos e torturados.

No segundo ato, acontecem os interrogatórios e eles são feitos no mês de setembro, início do outono no hemisfério norte, sendo que na mesma estação se dá a execução dos condenados (já no terceiro ato), em 14 de outubro. O outono está simbolicamente ligado ao declínio e à proximidade do fim, o que realmente acontece na peça com os amotinados. Porém, se considerarmos que o ciclo se iniciou na primavera, remetemo-nos ao conjunto das estações como símbolo de esperança, dado que elas retornam todos os anos (CHEVALIER; GHEERBRANT, 2003).

Pretendemos mostrar que esses ciclos se repetem em muitos níveis da peça, mas, estabelecendo um primeiro sentido a esse cronotopo carnaval, festa, taberna, vinho, tomamos as palavras de Bakhtin, que apontava, sobre a obra de Rabelais, que nas

[...] noitadas pantagruélicas, durante o pão o vinho e outras iguarias, realizam-se conversas pantagruélicas, conversas sábias, mas repletas de riso e licenciosidade [...] Todas as séries analisadas por nós servem para que Rabelais destrua o velho quadro do mundo, criado por uma época moribunda, e construa um novo, onde no centro encontra-se o homem total, corporal e espiritual. (BAKHTIN, 1999, p. 310-315).

Além disso, como afirma Clark (2004), o riso e o divertimento da festa estão intimamente associados à transição das estações, à renovação, e com ela o desejo de mudança, para uns (os amotinados), e o alerta do sentido de conservação, para outros ("instinto de conservação do que é nosso", na fala do próprio Mascarenhas).

4 Páscoa é também o nome da filha do taberneiro Tomás Pinto, que vê a sua liberdade e seu próximo casamento sacrificado pelos eventos que se seguirão. 
Franco escrevia, também, para destruir o "velho quadro" da ditadura portuguesa, fazendo uso do espaço-tempo da festa (e do teatro, como voltaremos a afirmar), assim como Bakhtin descreve a obra de Rabelais. Porém, no caso do dramaturgo, assim como no segundo ato da peça, o velho mundo ainda se revolta e se nega a ser destruído. A ditadura aspira ainda a sua eternidade e busca tornar infértil esse breve "hiato na tessitura" social (CLARK, 2004, p. 314), esse momento-espaço de insanidade, como se mencionou durante o relato da truculenta censura da peça, restabelecendo a ordem que é, verdadeiramente, a desordem da humilhação, da violência e da injustiça.

Não são, porém, apenas esses os sentidos assumidos pelo espaço da taberna e pelos ciclos envolvidos em seu principal item comercial. O vinho, elemento de simbologia altamente proficua, é descrito na peça de forma bastante relevante como a "vida do Porto" (FRANCO, 1963, p. 34). Com a taberna e, mais reconhecidamente, com o vinho, adentramos o espaço dos elementos sagrados.

A palavra latina taberna é utilizada para designar as vendas de vinho apenas após o século XIII. Antes disso, seu sentido ligava-se a um abrigo, a uma cabana ou choupana, e seu diminutivo, tabernaculu, nomeou os santuários que eram carregados pelos israelitas no deserto (HARPER, 2014). Mais tarde, o próprio Templo de Jerusalém viria a ser chamado de tabernáculo. Além disso, a palavra vai assumir outros significados no português contemporâneo, ligados ao misticismo cristão, como o ventre de Maria (tabernáculo da virgem) ou o local onde se encontra a Arca da Aliança (tabernáculo do Senhor) ou mesmo o céu (tabernáculo eterno) (MICHAELIS, 2014).

É possivel encontrar, por volta dos anos 1690, portanto ao tempo em que a palavra "taberna" já assumira o sentido de venda de vinho, o diminutivo da mesma palavra, "tabernáculo", significando "casa de adoração" (HARPER, 2014). Além de seu sentido etimológico, o espaço da taberna assume sacralidade ao ser não só o lugar da festa, mas também o do sacrificio e o da expiação. Lembremo-nos de que, no terceiro ato, a taberna é transformada em "oratório" para receber os condenados.

Se restasse alguma dúvida sobre a origem sagrada da taberna, ela seria imediatamente sanada com a verificação da importância que o vinho assume na religião, seja cristã, seja grega antiga.

$\mathrm{Na}$ cultura cristã, o vinho é o conhecido símbolo eucarístico do sangue de Cristo, que carrega consigo a mesma noção de sacrificio. Nos primórdios da arte cristã, a uva representava o reino dos céus, em que ingressava a alma de Cristo (LEXICON, 1997). Como já foi mencionado, na peça, o vinho é a "grande vida do Porto".

Da mesma maneira, temos a videira, julgada uma árvore sagrada na antiga Israel, e com a oliveira, que também será trazida para a peça, era considerada uma árvore messiânica. Vemos então as profundas conexões entre os elementos cronotópicos e a figura de Tomás Pinto, o "homem sem medo" (FRANCO, 1965, p. 134), personagem carismática em que se depositam as esperanças de reformas para a sua coletividade, um "messias social" . Fica clara a ligação que há entre o vinho e a taberna com a criação de um mártir. 
Estaremos ainda mais próximos dessas ideias se retornarmos à cultura grega e aos significados que ela impõe aos mesmos elementos. Na Grécia, o vinho era chamado de bebida da imortalidade, e a sua árvore, a videira, estava ligada ao renascimento, por seu caráter singular de planta que precisa ser podada para voltar a dar frutos. Assim, vê-se que há um ciclo de vida e morte associado a essa bebida.

A videira era consagrada a Dionísio (ou Baco), deus do vinho, bebida que representa a própria personificação do deus nas festas chamadas de "lenaionas", realizadas em fevereiro, portanto, na mesma época em que se dá o carnaval e o motim.

Além disso, o deus do vinho era acompanhado pelas bacantes ou mênades, etimologicamente, agitadas ou loucas, mas que formavam um grupo bastante importante nos ritos dionisíacos. Esse grupo encontra paralelo com as personagens da peça de Miguel Franco. Repare-se na semelhança entre a descrição das mulheres que participam da agitação inicial do motim e as bacantes, tais como são descritas em outra peça teatral, agora do grego Eurípedes.

Primeiro, vejamos a rubrica de $O$ motim:

Começa a ouvir-se um repique alegre, brados, vivas e gritos [...] O ulular da multidão é agora ensurdecedor [...] Gente do povo enche a adega. Muitos mascarados, maltrapilhos, de caras caiadas ou enfarruscadas. Mulheres desgrenhadas, descalças, descompostas [...] Tudo se agita ao ritmo da viola e dos ferrilhos e do tambor. Embriaguez. Frenesi. Sensualidade em desordem. Entra mais gente, saem alguns. Movimento vivo. [...] Pares agarrados saem também. (FRANCO, 1963, p. 21-25, grifo nosso).

Na peça de Eurípedes, o barulho característico do cortejo de Dionísio, tal como o descrito por Franco, é convocado pelo próprio deus, antes da entrada na cidade de Tebas: "Erguei os vossos tamborins oriundos da Frígia, por Reia-Madre e por mim achados. Que em redor da cidade de Penteu ressoem e toda a cidade de Cadmo vos olhe!" (EURÍPEDES, 1976, p. 77).

Em três passagens, Euripedes aproveita a fala de suas personagens para descrever o aspecto e o comportamento do "feminil tropel" que acompanha Baco.

Primeiro, repare que estão elas, assim como as mulheres de Franco, descalças: "Lá vi as bacantes, venerandas mulheres, que desta terra se foram, pés descalços, como por aguilhão tocadas" (EURÍPEDES, 1976, p. 101). Essas são as palavras do mensageiro que traz as novas a Penteu.

Outra característica semelhante, os cabelos desgrenhados, aparece mais de uma vez nas descrições das bacantes, a primeira abaixo feita pelo Coro e a segunda, mais uma vez, feita pelo Mensageiro para Penteu:

quando pelos montes correm os tíasos, é doce cair por terra [...] perseguir o corço e matá-lo, devorar-lhe as carnes sangrentas [...] os cabelos revoltos ao vento [...] pelos ombros soltam as ondas de seus cabelos, depois há as que deslaçadas havendo as nébrides, o veio pintado reajustam ao corpo, cingindo-o de serpentes que lhes lambem o rosto e abandonam os filhos e amamentam animais. (EURÍPEDES, 1976, p. 81-102, grifo nosso). 
Por fim, talvez o elemento mais importante a ser destacado, dada a descrição já citada de Bakhtin, seria a licenciosidade que aparece em conjunto, como dança, vinho e sexo, na descrição feita por Penteu: "nossas mulheres abandonam seus lares, correm pelos montes boscosos a venerar com danças um tal Dioniso. No meio dos tíasos, erguem-se crateras repletas de vinho. Por toda a parte, em ermos lugares se entregam ao prazer dos machos" (EURÍPEDES, 1976, p. 83).

Desse modo estão descritas as bacantes, em resumo, da mesma maneira como o foram por Miguel Franco: descalças, desgrenhadas e descompostas (agarradas aos pares - entregues ao prazer dos machos).

Notamos, enfim, formar-se um paralelo entre o culto de Dionísio e o motim, como se as personagens descritas incidentalmente por Franco fossem parte do próprio séquito de Baco taverneiro. Desse modo, é necessário identificar em que consiste esse culto e em que sentido tem valor o paralelo estabelecido entre as duas situações.

O culto ao deus do vinho assume, desde o princípio, um caráter de dualidade. Ao mesmo tempo em que se faz uma adoração ao ar livre, em uma busca de êxtase e alegria, com um caráter extremamente libertador, a veneração era permeada de uma brutalidade selvagem. Nesse aspecto, as bacantes eram tomadas de um "verdadeiro delírio assassino" (BRUNEL, 1997, p. 234), executando o dilaceramento de animais e, logo após, consumindo-lhes sua carne crua. Além disso, há a ingestão de grandes quantidades de vinho, que seria a própria representação da presença do deus nas festas.

As festas dionisíacas são realizadas na primavera, o que assume grande importância dentro da análise cronotópica da peça. Assim como o carnaval, o culto a Dionísio era um interregno social, momento em que tudo ficava em suspenso:

Em toda a Grécia nenhuma outra celebração se lhe podia comparar. Realizava-se na Primavera, quando a videira começa a vestir de parras e prolongava-se por cinco dias. E este período correspondiam tréguas totalmente sagradas $e$ o divertimento máximo. Todas as atividades normais da vida diária eram interrompidas; não se faziam prisões e os presos eram postos em liberdade, para que pudessem participar na rejubilação geral. (HAMILTON, 1983, p. 80).

Interessa destacar a proximidade dos "rituais carnavalescos" presentes no motim, e os rituais de Dionísio, ou seja, seu aspecto de mundo em suspenso, de festa regada a vinho, como bebida divina e libertadora.

A primavera se dá mais uma vez como renascimento, ou como marca de um ciclo, pois a videira, durante o inverno, parece morta, mas volta a dar folhas e frutos ao ser podada, ou, se quisermos, dilacerada, como Dionísio no mito ou como os seus seguidores no culto ou ainda como os amotinados após a sua condenação. A semelhança dos ciclos se dá, pois Dionísio é uma divindade "perseguida" e que sempre ressurge:

Ora é dilacerado, cozido e devorado pelos Titãs e Deméter o traz de volta à vida; ora Hera, em sua vingança, enlouquece a irmã de Sêmele, Ino, primeira mãe adotiva do deus, e os piratas o raptam para vendê-lo [...] Licurgo [...] persegue Dionísio e as ninfas que o criam; a criança apavorada joga-se no mar e Tétis o recolhe. (BRUNEL, 1997, p. 233). 
O deus ainda impõe esses ciclos aos seus seguidores, fazendo com que sofram as mesmas crueldades das quais fora vítima, recompensando-os, porém, com a mesma alegria do vinho.

Todo o culto torna-se ainda mais interessante em seu desenvolvimento histórico. Em outras palavras, as festas dionisiacas eram orgias ao ar livre em seus primórdios, mas, com o passar do tempo, tornam-se um outro ritual, que não se dava nem sequer em:

[...] um recinto de templo, onde os sacrificios se sucediam às cerimônias sacerdotais. Tratava-se, sim, de um teatro, e a cerimônia consistia na representação de uma peça. [...] As representações tinham um caráter sagrado; os espectadores tal qual os escritores e os atores, entregavam-se a um ato de devoção, a que se supunha que o próprio Dioniso assistia. (HAMILTON, 1983, p. 80, grifo nosso).

Destarte, o local sagrado da taberna, confunde-se com o local também sagrado do teatro. Da mesma forma, o ciclo primavera e outono, vida e morte, estão presentes tanto no entrecho da peça quanto no mito de Dionísio.

Pode-se dizer que as festas dionisiacas, em seus primórdios (as lenaionas) e em seu desenvolvimento ao se tornar teatro, assim como o carnaval, representa praticamente um "motim anual", momento em que tudo se inverte, procurando a própria renovação.

Um dos aspectos mais desconcertantes do culto de Dionísio é descrito por vários críticos e aparece na peça de Euripedes, em excerto destacado acima, em que se vê que as "mulheres abandonam seus lares" (EURÍPEDES, 1976, p. 83) e seu trabalho cotidiano. Isso faz de Dionísio um elemento de "contestação da ordem familiar", logo política (BRUNEL, 1997, p. 235). Ainda segundo Brunel (1997), é graças às mulheres que o culto de Dionísio se propaga. É interessante perceber que as mulheres, embora não apareçam como cabeças do motim do Porto, são as primeiras a participar do evento nas ruas. Remetemo-nos à dualidade masculino/feminino para estabelecer relação com outra, a de dominante/ dominado. Tanto no mito de Dionísio quanto em Eurípedes e em Franco, as mulheres procuram a desordem para a renovação de um equilíbrio social. No caso de Franco, as mulheres estão ainda fazendo a transformação dos cidadãos aceitos e respeitados em amotinados e, futuramente, condenados.

O ponto máximo da contestação se dá na peça do dramaturgo grego no momento em que Penteu vê desmoronar seu poder real pela presença do deus e de suas bacantes, sendo, ao fim, ele mesmo decapitado por sua mãe, Ágave, tocada pelo aguilhão de Baco.

Se isso não bastasse, o aspecto subversivo sobrevive em muito no teatro que, segundo Artaud, embora sem citar Dionísio, refere-se ao poder que o teatro tem de revelar "às coletividades seu poder sombrio, sua força oculta" (BRUNEL, 1997, p. 236).

O movimento de contestação social é evidentemente destacado em O motim e as semelhanças entre o seu líder e o deus se dão em mais um ponto. Tomás Pinto não é um homem do povo, mas assume a responsabilidade de lutar pelos seus interesses. Também Dionísio, pelo caráter de seu culto, é um "deus mais do povo que da aristocracia" (BRUNEL, 1997, p. 240). 
Cabe ainda mais uma referência aos elementos espaciais da peça de Miguel Franco, que conferem certa circularidade ao entrecho, referência que se pode tomar por mítica.

Apesar de a peça se passar sempre no mesmo local, algumas falas das personagens fazem menção a outro local. Trata-se do espaço em que começa o motim, "a rua do Olival" (FRANCO, 1963, p. 17). Esse será o mesmo sítio em que se executará a sentença dos condenados, que serão levados, nas palavras do Oficial de Justiça na peça, para a "alameda fora da porta do Olival, onde principiou essa horrenda sedição” (FRANCO, 1963, p. 126). É um dado histórico presente na Sentença da alçada (1786), mas a sua relevância assume na peça um aspecto simbólico interessante que se coaduna com os anteriormente vistos.

A oliveira (olival $=$ terreno plantado com oliveiras), juntamente com a videira, são as árvores consideradas messiânicas e nos remetem aos elementos já comentados sobre a personagem de Tomás Pinto e ao grupo que ele lidera. $\mathrm{O}$ óleo proveniente da oliva liga-se profundamente com a personagem que se sacrifica em nome de outros. A palavra hebraica para "messias" é a mesma para "ungido", untado com óleo. Além disso, lembremo-nos do Monte das Oliveiras, local sagrado para judeus, cristãos e muçulmanos, sendo que, para o Islã, a oliveira é o eixo do mundo e símbolo do profeta (CHEVALIER; GHEERBRANT, 2003, p. 657).

Interessa ressaltar que, no Cristianismo, o Monte das Oliveiras, além de sítio usado para alguns dos sermões de Cristo, assume um aspecto de ponto de partida, mas também de ponto de retorno. Conforme se lê nos Atos dos Apóstolos (Atos 1: 1-12), Jesus se reuniu pela última vez, após a Paixão e antes da Ascensão, com seus discípulos no Monte das Oliveiras e de lá ordenou que eles não se afastassem da cidade de Jerusalém. Já nas profecias de Zacarias (14: 3-5), lemos que, no dia de Iahweh, dia da volta de Deus, ele colocará seus pés primeiramente no Monte das Oliveiras, que "se rachará pela metade" (Zacarias 14: 4).

Vemos assim que a partir de um mesmo ponto, ocorre a Ascensão (um primeiro desaparecimento), mas também o retorno vitorioso. Um novo ciclo se insinua, então, em relação aos amotinados que têm seu primeiro momento de glória na rua do Olival, mas são lá, posteriormente, sacrificados. Surge, então, o último significado da oliveira: força, vitória, recompensa e, futuramente, o paraíso dos eleitos (CHEVALIER; GHEERBRANT, 2003, p. 657).

Em síntese, como Dionísio nasce do amor de Zeus e Sêmele, é dilacerado e renasce em seus diversos ciclos, o espaço do motim (a taberna e o teatro) sofre, a princípio, o mesmo efeito. O espaço inicial, de congraçamento e igualdade entre os homens, passa por um processo de degradação que o leva à total desfiguração. Porém, acreditando-se que todos os paralelos estabelecidos possuem um momento de renascimento, devemos supor o mesmo para a taberna e para os amotinados. Dessa forma, o ciclo se pode dar em três niveis, em um primeiro simbólico: vinho, videira e Dionísio. Segundo nível: no entrecho da peça, o tempo e o espaço, a taberna e o carnaval. Por último, em um terceiro nível, no próprio contexto histórico da ditadura portuguesa, em que se enfrenta o momento do dilaceramento, mas ainda não o do renascimento. O entendimento dos ciclos, no entanto, nos leva aos elementos mais importantes, o da resistência e o da certeza do renascimento, mas, acima de tudo, o do desejo de renovação. 
Enfim, a análise do cronotopo parece justificar o rótulo de elemento estruturante que procuramos adiantar. Como ressaltamos ao início do artigo, o cronotopo pode ser visto em dois níveis e foi possivel perceber que todos os elementos relacionados ao primeiro deles (tempo e espaço) que analisamos, apontam sempre para um mesmo sentido. Isso pode nos insinuar uma tentativa de se remeter a um caráter genérico, elocutório, em direção a todas as narrativas que tratam de ciclos de renovação necessária para que a vida tenha seguimento.

É preciso, em outros termos, que haja um "motim" para que cada ciclo se encerre e para que a vida possa se renovar e continuar. Esse motim pode ser uma festa popular como o carnaval, uma lenaiona dionisiaca ou um levante popular contra as injustiças das autoridades e das classes dominantes. Já no contexto histórico de Miguel Franco, tudo o que foi visto nos mostra que a resistência e a participação popular são imprescindiveis para que qualquer movimento histórico tenha o seu início.

\section{O MOTIM, BY MIGUEL FRANCO: A SACRED CYCLE OF RENOVATION}

Abstract: This paper aims at analyzing the chronotropic elements of the play $O$ Motim, by Miguel Franco (1963), seeking to understand the meaning that they attach to the piece.

Keywords: Theatre (literature) (History and Criticism) - Portugal. Historical drama. Miguel Franco. O Motim.

\section{REFERÊNCIAS}

AMORIM, M. A. Festas carnavalescas: o avesso e o plural na folia. Salto Para o Futuro: aprender e ensinar nas festas populares, Rio de Janeiro: SEED-MEC, boletim 2, p. 28-39, abr. 2007.

BAKHTHIN, M. M. Cultura popular na Idade Média e no Renascimento: O Contexto de François Rebelais. São Paulo: Hucitec, 1999.

BAKHTIN, M. M. Problemas da poética de Dostoiévski. Tradução Paulo Bezerra. Rio de Janeiro: Forense Universitária, 2005.

BAKHTIN, M. M. Questões de literatura e de estética: a teoria do romance. São Paulo: Hucitec, 2010.

BOTTON, F. F. Entre Clio e Caliope: literatura e história no teatro de Miguel Franco. 2015. Tese (Doutorado em Literatura Portuguesa)-Universidade de São Paulo, São Paulo, 2015.

BRUNEL, P. (Org.). Dicionário de mitos literários. Rio de Janeiro: José Olympio, 1997.

CHEVALIER, J.; GHEERBRANT, A. Dicionário de simbolos. Rio de Janeiro: José Olympio, 2003. 
CLARK, K.; HOLQUIST, M. Mikhail Bakhtin. Tradução Jacó Guinsburg. São Paulo: Perspectiva, 2004.

SANTOS, V. P (Org.). Companhia Rey Colaço Robles Monteiro: 1921-1974. Lisboa: Museu Nacional do Teatro, 1987.

EURÍPEDES. Medeia e As bacantes. Tradução Miroel Silveira e Junia Silveira Gonçalvez. São Paulo: Abril Cultural, 1976. Tradução de As Bacantes, por Eudoro de Souza.

FRANCO, M. O motim. 1ª edição. Lisboa: Edição do autor, 1963.

FRANCO, M. O motim. 2 ${ }^{\text {a }}$ edição. Lisboa: Europa-América, 1965.

HARPER, D. Online Etymology Dictionary. 2014, Verbete: tabernacle, tavern. Disponivel em: <http://www.etymonline.com/>. Acesso em: 11 abr. 2014.

LEXICON, H. Dicionário de símbolos. São Paulo: Cultrix, 1997.

MICHAELIS - Dicionário de Português on-line. 2015. Verbete: tabernáculo, taberna. Disponivel em: <http://michaelis.uol.com.br/moderno/portugues/>. Acesso em: 11 abr. 2014.

OLIVEIRA, A. C. S. Homens de oficio: práticas politicas durante o reinado de D. João I de Portugal (1385-1433). In: XVIII SEMANA DE HISTÓRIA/ VI FÓRUM DE PESQUISA E PÓS-GRADUAÇÃO EM HISTÓRIA/I FÓRUM DE LICENCIATURA EM HISTÓRIA, 2012, Maringá. Congresso. Maringá: Universidade Estadual de Maringá, 2012.

Sentença da alçada, que el-Rey Nosso Senhor mandou conhecer da rebelliaõ succedida na cidade do Porto em 1757, Lisboa, Oficina de Antonio Rodrigues Galhardo, Impressor da Real Mesa Censória, 1786. Com licença da mesma Real Mesa.

Recebido em 24-06-2016. Aprovado em 04-10-2016. 